\title{
Influence of Spring Burning on Cattle Diets and Performance on the Edwards Plateau
}

\author{
ALLAN MCGINTY, FRED E. SMEINS, AND LEO B. MERRILL
}

\section{Abstract}

Immediately following spring burning of Edwards Plateau rangeland, steer diets had a higher percentage of grass and lower percentage of forbs than diets from unburned range. Intake of pricklypear cactus was greater on burned range than on unburned during the first summer and fall following the fire. Ash content of steer diets in the burn was generally higher, due primarily to increased use of pricklypear cactus on burned sites. Steer diets from burned range contained significantly higher in vitro digestible organic matter (IVDOM) during June. Increased use of pricklypear cactus contributed to a significantly higher IVDOM during September and October and lower percent crude protein from September to November in the burn. Heifers gained significantly more on burned range during June and August and also when averaged across the entire 5-month grazing period. Burning has potential as a useful tool to increase cattle production from Edwards Plateau rangeland.

Fire is recognized as a major ecological factor in many rangeland ecosystems (Daubenmire 1968) and is gaining acceptance as a range improvement tool (Scifres 1980). Livestock prefer burned to unburned areas (Humphrey 1949) and generally have greater weight gains on burned areas (Anderson 1960, Anderson et al. 1970, Woolfold et al. 1973). Anderson (1964) reported increased gains following late spring burning in the Kansas Flint Hills and attributed this to increased protein content and digestibility of little bluestem (Schizachyrium scoparium). Greene (1935) reported a $14.5 \mathrm{~kg} / \mathrm{yr} / \mathrm{head}$ increase in steer gains following annual winter burning in the longleaf pine (Pinus palustris) belt and noted that two-thirds of this advantage in gain was made before June of each year. Hilmon and Hughes (1965) found that cattle gain increased 17 and $39 \mathrm{~kg} / \mathrm{ha}$ after burning timbered range in Georgia and Florida, respectively. This increase in gain was attributed to greater palatability, quality, and production of wiregrass following burning. In Mississippi Greene (1929) reported annual burning of bluestem pastures increased cattle gain by $20 \mathrm{~kg} / \mathrm{ha}$. Greene attributed this increased gain to greater availability of green forage on burned pastures, and noted that the best gain occurred 60 to 90 days following the fire, with no difference in gain between burned and unburned pastures after that time. In Florida, Kirk and Hodges (1970) reported annual winter burning of half of the range each year increased weaned calf crop from 53 to $69 \%$, gain/calf from 10.1 to $13.1 \mathrm{~kg} / \mathrm{ha}$, and gain/cow from 81.6 to $106.1 \mathrm{~kg}$.

No published data relating livestock performance to prescribed burning are available for Texas rangelands. Little data a re available from any area which relates animal gains following burning to changes in livestock diet quality or composition. The purpose of this investigation was to determine the influence of burning on botanical and nutrient contents of diets and cattle gains on Edwards Plateau rangeland.

\footnotetext{
Authors ate, respectively, Extension range specia list, Texas Agricultural Extension Service, Fort Stockton; professor, Department of Range Science, Texas A\&M University, College Station; and professor, Texas A\&M University Agricultural Research Station, Sonora. At the time of this research, McGinty was a research assistant, Department of Range Science, Texas A\&M University.

This report is published with approval of the Director, Texas Agricultural Experiment Station as TA.

Manuscript received May 20, 1981
}

\section{Study Area}

The study was conducted on the George Brockman Ranch near Sonora, Texas, in the Edwards Plateau. The Edwards Plateau is a partially dissected remnant of an uplifted plain capped chiefly by resistant limestones (Long 1962). Soils on the study area are Lithic Haplustolls of the Tarrant and Kavett series (Wiedenfeld and McAndrew 1968). Climate of the area is semiarid, mesothermal with an average annual evapotranspiration and rainfall of approximately 90 and $57 \mathrm{~cm}$, respectively. May and September are the wettest months and average about $8 \mathrm{~cm}$ of precipitation each. Droughts are common and $53 \%$ of the years have below-average precipitation. Edwards Plateau summers are warm and dry with an average July temperature of $30^{\circ} \mathrm{C}$. Average January temperature is $9^{\circ} \mathrm{C}$ (Long 1962).

The study area lies within the live oak-Vasey shin oak (Quercus virginiana-Quercus pungens var vaseyana') vegetation type (Harris 1958). Dominant herbaceous plants on the study site included common curlymesquite (Hilaria belangeri), threeawn (Aristida spp.), sideoats grama (Bouteloua curtipendula), hairy tridens (Erioneuron pilosum), Texas wintergrass (Stipa leucotricha), red grama (Bouteloua trifida) and sedges (Carex spp.). Woody plants of importance were live oak, Va sey shin oak, Texas persimmon (Diospyros texana), honey mesquite (Prosopis glandulosa var glandulosa), ashe juniper (Juniperus ashei), redberry juniper (Juniperus pinchoti), and lotebush (Condalia obtusifolia).

Vegetation of the area has changed significantly due to past overgrazing by livestock and elimination of fires (Bray 1906). Until approximately 1945 the Brockman Ranch was stocked with cattle, sheep, and goats at a yearlong rate of 3.0 to 4.0 ha/ AU. From 1945 to the present the yearlong stocking rate was $8.5 \mathrm{ha} / \mathrm{AU}$, with cattle, sheep, and goats.

A 162-ha fenced pasture which was representative of the soils, topography, and grazing history on the ranch, was selected for study. Range condition on the low stony hill range site was rated as mid-good using Soil Conservation Service evaluation procedures. Within the past 5 years selected woody plants, particularly juniper and honey mesquite, had been mechanically cleared.

\section{Methods}

The study pasture was divided with electric fences into 4 paddocks of 40 ha each. Two paddocks were randomly assigned as control replications while the remaining 2 were burned with a headfire on March 1, 1977.

Standing fine fuel load at the time of the prescribed burn was $2,800 \mathrm{~kg} / \mathrm{ha}$, while fuel and soil moistures were 6.7 and $23.7 \%$, respectively. Air temperature at the time of burning was $11^{\circ} \mathrm{C}$, relative humidity was $50 \%$ and wind $13 \mathrm{kph}$ with gusts to $21 \mathrm{kph}$ (McGinty 1979). Precipitation was measured during the period of study with 2 standard Weather Bureau rain gauges (Table 1).

All paddocks were deferred 3 months before and after the burn. They were then grazed with cattle for 5 months (May 28, 1977, to October 28,1977 ) at a year-long stocking rate of 6.5 ha/AU. Stocking density for the grazing period was $2.7 \mathrm{ha} / \mathrm{AU}$.

To determine weight gain performance, uniform yearling Hereford heifers were selected from a common herd of cattle on the

Taxonomic nomenclature follows Gould (1975). 
Table 1. Precipitation record $(\mathrm{cm})$ for the study area from March 1977 to October 1977 and the long-term monthly precipitation averages.

\begin{tabular}{lccc}
\hline \hline & $\begin{array}{c}\text { Precipitation } \\
\text { during study } \\
\text { period }\end{array}$ & $\begin{array}{c}\text { Summation by } \\
\text { month during } \\
\text { study period }\end{array}$ & $\begin{array}{c}\text { 40-year } \\
\text { average } \\
\text { summation } \\
\text { by month }\end{array}$ \\
\hline $03 / 26 / 77$ & 5.9 & 5.9 & 1.6 \\
$04 / 14 / 77$ & 10.5 & & \\
$04 / 19 / 77$ & 1.8 & 13.7 & 3.9 \\
$04 / 20 / 77$ & 1.4 & & \\
$05 / 08 / 77$ & 1.7 & & \\
$05 / 11 / 77$ & 1.4 & 4.5 & 7.4 \\
$05 / 21 / 77$ & 1.4 & & 6.0 \\
$06 / 07 / 77$ & 3.1 & 4.2 & 4.4 \\
$06 / 24 / 77$ & 1.1 & 0.2 & \\
$07 / 28 / 77$ & 0.2 & & 3.6 \\
$08 / 10 / 77$ & trace & 3.4 & 4.4 \\
$08 / 13 / 77$ & 3.4 & 1.9 & 4.9 \\
$09 / 05 / 77$ & 1.9 & & 36.2 \\
$10 / 22 / 77$ & 5.1 & 5.7 & \\
$10 / 27 / 77$ & 0.6 & & \\
Total & & & \\
\hline
\end{tabular}

ranch. Four heifers were randomly assigned to each paddock. Average initial weight for heifers in the burned paddocks was 234 $\mathrm{kg}$, and for the control was $240 \mathrm{~kg}$. Heifers were weighed at 30-day intervals to establish rate of gain during the grazing period. Mature cows were added to stock paddocks at the required level.

To determine botanical and chemical composition of diets, 3 esophageally cannulated Angus steers were used. Diet samples were collected from the burn and control paddocks during the morning for 3 consecutive days each month during the 5 month grazing period. For a collection, animals were allowed free movement across the sample paddock for a period of $\mathbf{3 0}$ minutes to an hour. Cannulated steers were penned overnight prior to the first collection and during the entire 3-day collection period to reduce contamination of samples by regurgitation. When not being used during a collection period steers were kept on pastures similar to the study area. Steers were fitted with a screen-bottom canvas bag to collect ingested forage (Edlefsen et al. 1960). From each collection a subsample was removed and air dried at room temperature for later determination of botanical composition and chemical characteristics of the diet.

Botanical composition of diets was evaluated following procedures described by Kothmann (1968) with the following modifications. Each sa mple was thoroughly mixed and spread evenly across a poster board containing 100 rand omly placed points. The nearest plant fragment to each point was then identified microscopically as forb, browse species, grass species, pricklypear cactus, and whether live or dead.

Following botanical analysis, forage samples were ground

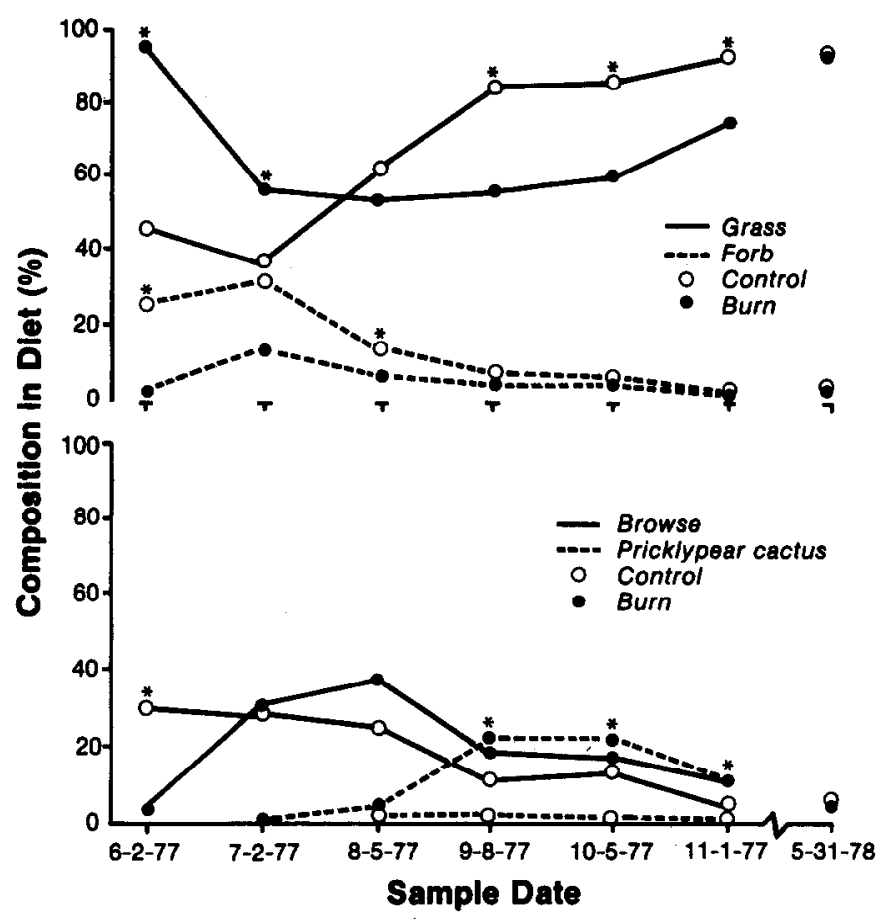

Flg. 1. Percent grasses, forbs, browse and pricklypear cactus in steer diets from control and burn paddocks. Significant differences ( $\mathbf{P} \leq 0.05$ ) between burn and control paddocks by date within a forage class are indicated by an asterisk.

through a Wiley mill (mesh size of 24) for chemical analysis. Crude protein $(\% \mathrm{~N} \times 6.25)$ was determined for each diet sample by the micro Kjeldahl method (A.O.A.C. 1960). In vitro digestible organic matter, as well as percent ash in the diet was determined using procedures of Van Soest et al. (1966), with the procedure modified to correct values to apparent digestible organic matter by use of a standard feed.

All data were analyzed using standard analysis of variance techniques. Mean separation was performed with Duncan's new multiple range test (Ott 1977).

\section{Results}

\section{Diet Botanical Composition}

Grass contributed a higher percentage of the diet in the burn than in the unburned paddocks during June and July, but this pattern reversed for September, October, and November (Fig. 1). The grass component of both the burn and control diets was composed primarily of common curlymesquite grass and Texas wintergrass with lesser amounts of threeawn, sideoats grama, vinemesquite (Panicum obtusum) and other miscellaneous grasses (Table 2).

Forbs contributed a greater percentage of the diet in unburned paddocks as compared to burned paddocks during June, July and August (Fig. 1). During these months, forb availability on the burn was much reduced by the fire. Redseed plaintain (Plantago rhodo-

Table 2. Percent composition of grass species in steer diets.

\begin{tabular}{|c|c|c|c|c|c|c|c|c|c|c|c|c|c|c|}
\hline \multirow[b]{2}{*}{ Species } & \multicolumn{2}{|c|}{$6 / 2 / 77$} & \multicolumn{2}{|c|}{$7 / 2 / 77$} & \multicolumn{2}{|c|}{$8 / 15 / 77$} & \multicolumn{2}{|c|}{$9 / 8 / 77$} & \multicolumn{2}{|c|}{$10 / 5 / 77$} & \multicolumn{2}{|c|}{$11 / 1 / 77$} & \multicolumn{2}{|c|}{$5 / 31 / 78$} \\
\hline & Burn & Control & Burn & Control & Burn & Control & Burn & Control & Burn & Control & Burn & Control & Burn & Control \\
\hline $\begin{array}{l}\text { Curlymesquite } \\
\text { Texas wintergrass } \\
\text { Threeawn spp. } \\
\text { Sideoats grama } \\
\text { Sedge spp. } \\
\text { Vine mesquite } \\
\text { Miscellaneous }\end{array}$ & $\begin{aligned} 27 \mathrm{a}^{1} \\
35 \mathrm{a} \\
<1 \mathrm{~b} \\
11 \mathrm{a} \\
1 \mathrm{a} \\
8 \mathrm{a} \\
12 \mathrm{a}\end{aligned}$ & $\begin{aligned} 11 b \\
18 b \\
3 a \\
3 b \\
2 a \\
2 b \\
6 a\end{aligned}$ & $\begin{array}{r}27 \mathrm{a} \\
7 \mathrm{a} \\
1 \mathrm{a} \\
4 \mathrm{a} \\
1 \mathrm{a} \\
6 \mathrm{a} \\
9 \mathrm{a}\end{array}$ & $\begin{array}{r}13 \mathrm{~b} \\
6 \mathrm{a} \\
1 \mathrm{a} \\
2 \mathrm{a} \\
2 \mathrm{a} \\
4 \mathrm{a} \\
8 \mathrm{a}\end{array}$ & $\begin{array}{r}30 \mathrm{a} \\
7 \mathrm{a} \\
3 \mathrm{a} \\
2 \mathrm{a} \\
0 \mathrm{a} \\
4 \mathrm{a} \\
6 \mathrm{a}\end{array}$ & 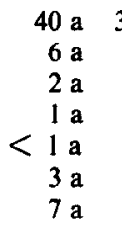 & $\begin{array}{r}36 \mathrm{a} \\
4 \mathrm{a} \\
4 \mathrm{a} \\
2 \mathrm{a} \\
1 \mathrm{a} \\
2 \mathrm{a} \\
5 \mathrm{a}\end{array}$ & $\begin{array}{r}57 \mathrm{~b} \\
10 \mathrm{a} \\
4 \mathrm{a} \\
1 \mathrm{a} \\
0 \mathrm{a} \\
2 \mathrm{a} \\
8 \mathrm{a}\end{array}$ & $\begin{array}{r}48 \mathrm{a} \\
3 \mathrm{a} \\
4 \mathrm{a} \\
<1 \mathrm{a} \\
<1 \mathrm{a} \\
<1 \mathrm{a} \\
13 \mathrm{a}\end{array}$ & $\begin{array}{rl}68 & \mathrm{~b} \\
5 & \mathrm{a} \\
3 \mathrm{a} \\
1 \mathrm{a} \\
2 \mathrm{~b} \\
1 \mathrm{a} \\
3 \mathrm{a}\end{array}$ & $\begin{array}{r}53 \mathrm{a} \\
12 \mathrm{a} \\
3 \mathrm{a} \\
<1 \mathrm{a} \\
<1 \mathrm{a} \\
<1 \mathrm{a} \\
1 \mathrm{1}\end{array}$ & 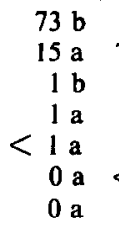 & $\begin{aligned} 6 \mathrm{a} \\
77 \mathrm{a} \\
1 \mathrm{a} \\
1 \mathrm{a} \\
3 \mathrm{a} \\
<1 \mathrm{a} \\
2 \mathrm{a}\end{aligned}$ & $\begin{array}{r}15 \mathrm{a} \\
62 \mathrm{~b} \\
4 \mathrm{a} \\
1 \mathrm{a} \\
5 \mathrm{a}\end{array}$ \\
\hline
\end{tabular}

'Means in the same row for the same date followed by a common subscript are not significantly different at the .05 level of probability. 
sperma) was the dominant forb in the study area. This species overwinters in the rosette form and thus was severely damaged by the early spring burn. Percentage of forbs in diets decreased almost linearly as forb availability on the burn and control decreased with advancement of the growing season and in response to low rainfall during the summer (Table 1).

Percentage browse in steer diets was similar between the burn and control paddocks except in June when there was a higher percentage of browse in the steer diets from the control paddocks (Fig. 1). On this date, $97 \%$ of the diet in the burned paddocks was composed of grass. At this time grass in the burn was higher in crude protein content and percent live phytomass as compared to the control and was apparently highly selected (McGinty 1979).

Pricklypear cactus percentage in steer diets, primarily cactus damaged by fire, was higher on burned paddocks from September through November, 1977 than unburned paddocks (Fig. 1). Pricklypear cactus comprised from 12 to $23 \%$ of steer diets on the burn during this period, but never contributed over $1 \%$ of the diet on unburned paddocks.

The percentage of live plant material in steer diets, from the burned paddocks was significantly higher as compared to the unburned paddocks in June, 1977 (Fig. 2). Apparently fire removal of dead plant material resulted in greater accessibility of green plant phytomass to the grazing animal. No significant difference between the burn and control in terms of green plant content of the diet occurred after the June sample date.

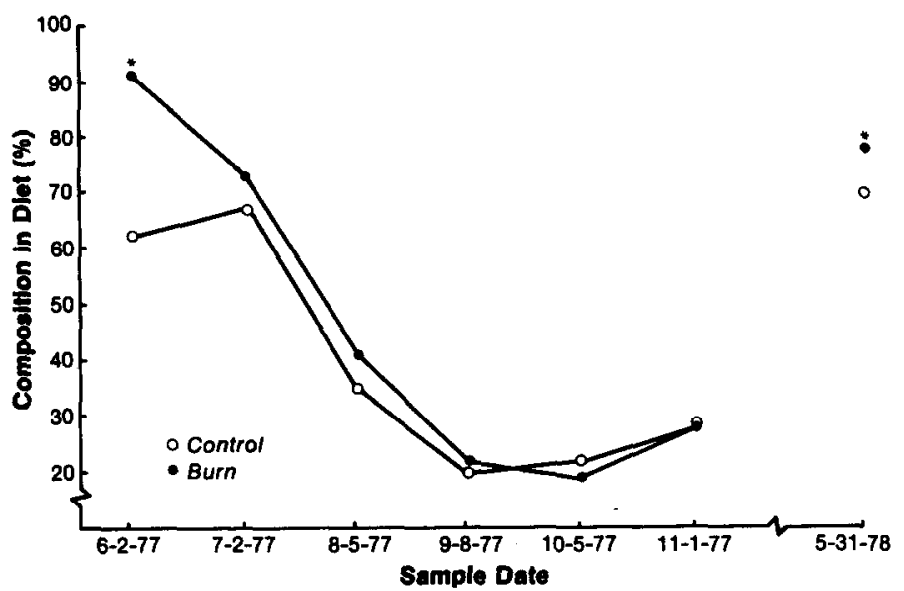

Fig. 2. Percent live phytomass in steer diets from burn and control paddocks. Significant differences ( $\mathrm{P} \leq 0.05)$ between the burn and control paddocks for a date are indicated by an asterisk.

\section{Diet Quality}

The ash content of steer diets from the burn paddocks exceeded those from the control paddocks from September through November (Fig. 3). This increase corresponded to increased pricklypear cactus consumption in the burn.

In vitro digestible organic matter content (IVDOM) of steer diets from the burn paddocks was greater than the control paddocks during June, Septcmber, and October sample dates (Fig. 3) and agrees with Añderson (1964), who also found increased digestiblity of forage following burning. The significant increase of digestibility for the burn as compared to the control paddocks in June was probably due in part to the greater percentage of live plant material in the diet from the burned paddocks compared to the control. The higher IVDOM for September and October diets in the burn paddocks was due primarily to increased pricklypear cactus consumption, which is high in soluble ash (Fraps and Cory 1940).

Percent crude protein on a dry matter basis for steer diets from the control paddocks exceeded those from burn paddocks in September, October and November (Fig. 4). Crude protein content of steer diets from the burn paddocks did not increase initially following the burn as compared to those from the control paddocks

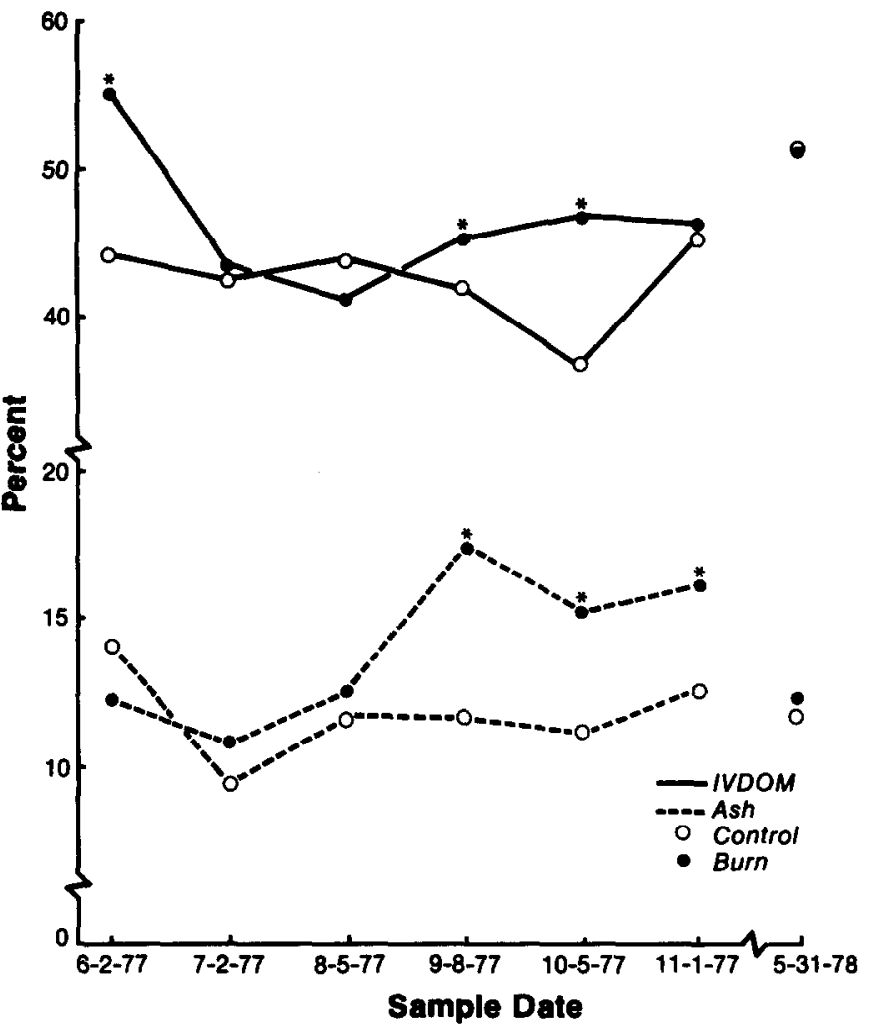

Fig. 3. Ash content and in vitro digestible organic matter (IVDOM) of steer diets from burn and control paddocks. Significant differences $(\mathrm{P} \leq 0.05)$ between burn and control paddocks for a date are indicated by an asterisk.

although clipped grass samples (McGinty 1979) did show elevated crude protein contents. This may be due in part to a lower use of forbs on the burn. Since redseed plaintain, the major forb in the study area, was reduced in availability by the burn, steers consumed more grass and this apparently depressed the crude protein content of the diet. Lower crude protein content of both the burn and control diets during the summer was due primarily to low precipitation that slowed or stopped plant growth (Table 1). Crude protein content of steer diets from the burned paddocks decreased

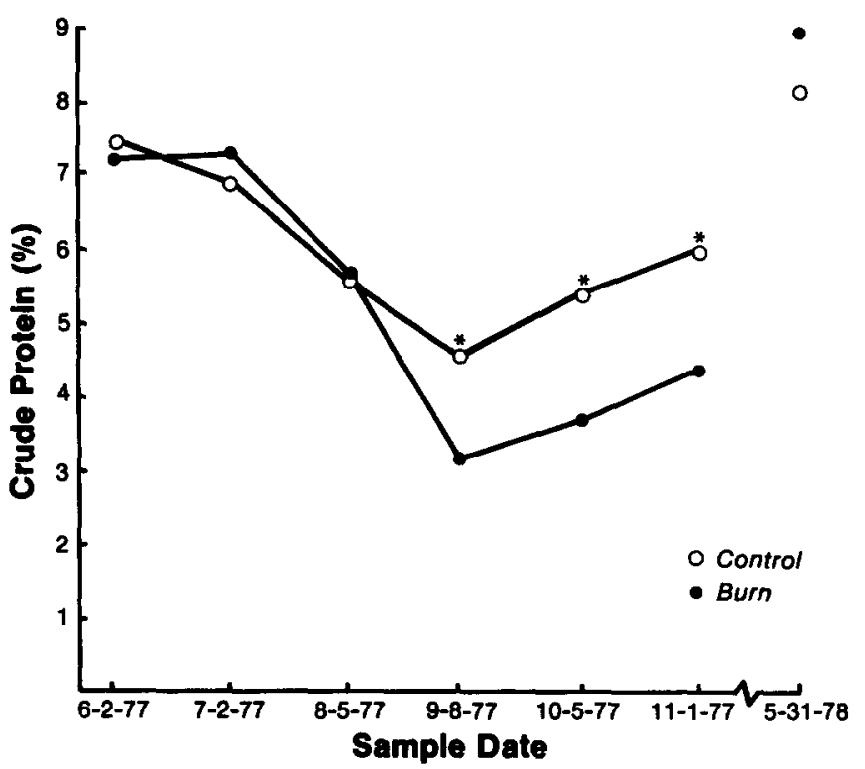

Fig. 4. Crude protein (dry weight) of steer diets from burn and control paddocks. Significant differences $(\mathrm{P} \leq 0.05)$ between burn and control paddocks for a date are indicated by an asterisk. 


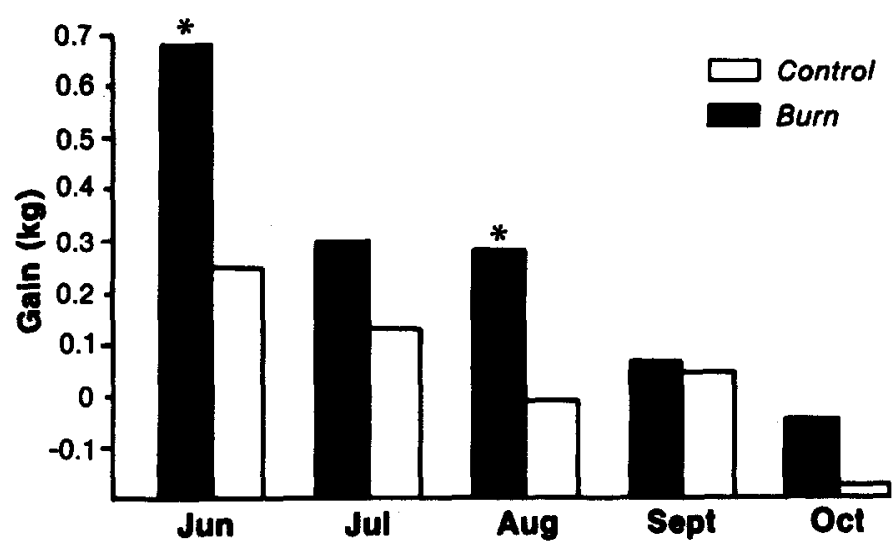

Fig. 5. Average daily gain $(\mathrm{kg})$ of heifers in burn and control paddocks. Significant differences ( $\mathrm{P} \leq 0.05$ ) between burn and control for a date are indicated by an asterisk.

in September, October, and November due to high use of pricklypear cactus.

\section{Weight Gain}

Heifer gains on the burn paddocks were positive from June through September, while gains on the control paddocks were positive in June, July, and September (Fig. 5). Rate of gain on the burn paddocks exceeded that of control paddocks in June and August. Across the 155-day grazing period rate of gain was significantly higher on the burn $(0.28 \mathrm{~kg} / \mathrm{hd} / \mathrm{da})$ than on the control $(0.05$ $\mathrm{kg} / \mathrm{hd} / \mathrm{da}$ ). Other researchers have documented higher gains by cattle following burning (Anderson 1960, Hilmon and Hughes 1965, and Kirk and Hodges 1970).

\section{Literature Cited}

Anderson, K.L. 1960. Burning bluestem ranges. Crops and Soils 13:13-14. Anderson, K.L. 1964. Burning flint hills bluestem ranges. Proc. Tall Timbers Fire Ecol. Conf. 3:89-104.

Anderson, K.L., E.F. Smith, and C.E. Owensby. 1970. Buming bluestem range. J. Range Manage. 23:81-91.

A.0.A.C. 1960. Official methods of analysis (9th ed.) Ass. Off. Agr. Chem., Washington, D.C
Bray, W.L. 1906. Distribution and adaptation of the vegetation of Texas. Univ. Texas Bull. 83.

Daubenmire, R. 1968. Ecology of fire in grasslands. Adv. Ecol. Res. 5:209-266.

Edlefsen, J.L., C.W. Cook, and J.T. Blake. 1960. Nutrient content of the diet as determined by hand plucked and esophageal fistula samples. J. Anim. Sci. 19:560-567.

Fraps, G.S., and V.L. Cory. 1940. Composition and utilization of range vegetation of Sutton and Edwards Counties. Tex. Agr. Exp. Sta. Bull.

Gould, F.W.1975. Texas plants-a checklist and ecological summary. Tex. Agr. Exp. Sta. MP-5851 revised.

Greene, S.W. 1929. The stockman's interest in protecting forest and range from fire. South. For. Long. Proc. 33:338-344.

Greene, S.W. 1935. Relation between winter grass fires and cattle grazing in the longleaf pine belt. J. Forest. 33:338-341.

Harris, V.M. 1958. Ecology, control and management of shin oak on the Edwards Plateau. Ph.D. Diss., Texas A\&M Univ., College Station.

Hilmon, J.B., and R.H. Hughes. 1965. Fire and forage in the wiregrass type. J. Range Manage. 18:251-254.

Humphrey, R.R. 1949. Fire as a means of controlling velvet mesquite, burroweed, and cholla on southern Arizona ranges. J. Range Manage. 2:175-182.

Kirk, W.G., and F.M. Hodges. 1970. Effect of controlled burning on production of cows on native range. Soil Crop Sci. Soc. Fla. Proc. 30:341-343.

Kothmann, M.M. 1968. The botanical composition and nutrient content of the diet of sheep grazing on poor condition pasture compared to good condition pastures. Ph.D. Diss., Texas A\&M Univ., College Station.

Long, A.T. 1962. Ground water geology of Edwards County, Texas. Water Develop. Board Bull. 6208.

McGinty, A. 1979. Soil, vegetation and livestock responses following spring burning of Edwards Platea rangeland. Ph.D. Diss., Texas A\&M Univ., College Station.

Ott, L. 1977. An Introduction to Statistical Methods and Data Analysis. Duxberg Press, Belmont, Calif.

Scifres, C.J. 1980. Brush Management. Texas A\&M Univ. Press, College Station.

Van Soest, P.J., R.H. Wine, and L.A. Moore. 1966. Estimation of true digestibility of forage by the in vitro digestion of cell walls. Proc. 10th Int. Grassland Cong. 10:438-441.

Wiedenfeld, C.A., and J. McAndrew. 1968. Soil survey, Sutton County, Texas. U.S. Dept. of Agr. Soil Cons. Ser. and Tex. Agr. Exp. Sta. 33 p.

Woolfold, J.S., C.E. Owensby, L.H. Harlens, R.R. Schalles, L.J. Allen, and E.F. Smith. 1973. Response of yearling steers to burning, fertilization and intensive early season stocking of bluestem pastures. Kan. Agr. Exp. Sta. Bull, 568:10-12. 